\title{
Bomb-spike dating of a mummified baboon in Ludwig Cave, Namibia
}

\author{
Greg Hodgins ${ }^{1}$, George A. Brook ${ }^{2}$ and Eugene Marais ${ }^{3}$
}

\begin{abstract}
:
Hodgins G., Brook G.A. and Marais E. 2007. Bomb-spike dating of a mummified baboon in Ludwig Cave, Namibia. International Journal of Speleology, 36 (1), 31-38. Bologna (Italy). ISSN 0392-6672.

In 1982 a mummified adult female baboon was discovered on a ledge in Ludwig Cave in Namibia. A toe bone was removed for dating in July 1995. AMS radiocarbon dating of bone collagen, tendon, and skin indicates a post-modern age. Application of the atomic bomb-spike calibration curve suggests death in late 1977 and an age at death of around 19 years. Baboons roost in the cave and the mummified female, along with a mummified juvenile male discovered in 2002 and three rotting corpses discovered in 1995, were probably chased by other baboons or by leopards down a ca. $6 \mathrm{~m}$ drop during the rainy season, and were unable to climb the steep and very slippery slope to escape. The large number of baboons trapped in the cave in less than 20 years, and mummification of two individuals on dry, dusty ledges in the cave, may explain why large numbers of baboon skeletons have been discovered in ancient bone breccias (up to $4 \mathrm{Ma}$ old) in a number of caves throughout Southern Africa.
\end{abstract}

Keywords: mummified animals, baboons, caves, bomb-spike dating, radiocarbon, Namibia, Otavi Region, Ludwig Cave.

Received 20 June 2006; Revised 17 October 2006; Accepted 16 November 2006

\section{INTRODUCTION}

Caves are natural traps and as such are important repositories for both animal and human remains. Hominid remains dating to $>4$ Ma have been recovered from breccias in South African caves such as Sterkfontein, Swartkrans, and Kromdraai (e.g. Brain, 1981). Uncemented remains of animals are commonly found in the caves of arid lands. For example, bones of a Giant Ground Sloth (Glossotherium harlani), that may have weighed $900 \mathrm{~kg}$, were recovered from a chamber ca. $64 \mathrm{~m}$ underground in Grand Canyon Caverns, in western Arizona. The Giant Sloth became extinct between 20 and $11 \mathrm{ka}$. In the same cave a mummified bobcat was found ca. AD 1950 and was presumed to be about 100 years old at that time (www. desertusa.com).

In fact, naturally mummified animals are frequently encountered in arid land caves due to localized dry microclimates that prevent decay. Commonly, the animal falls into the cave or enters via steep or slippery slopes and cannot escape. A difficult entry also denies access to scavenging animals, thus preserving the carcass. In arid areas, animals trapped in caves can

${ }^{1}$ NSF-Arizona AMS Laboratory, Department of Physics,

University of Arizona, Tucson, AZ 85721, USA. (email:

ghodgins@physics.arizona.edu)

${ }^{2}$ Department of Geography, University of Georgia, Athens, GA

30602, U.S.A. (email: gabrook@uga.edu).

3Entomology Centre, National Museum of Namibia, P.O. Box

1203, Windhoek, Namibia (email: insects@natmus.cul.na). be mummified and preserved for thousands of years due to the exceptionally dry conditions. For example, in 1965 a mummy of the now extinct marsupial Tasmanian tiger (Thylacinus cynocephalus) was discovered in Thylacine Hole in the Nullarbor Plain of Western Australia (Lowry \& Lowry, 1967; Lowry \& Merrliees, 1969). The mummy was radiocarbon dated to $4600-4700{ }^{14} \mathrm{C}$ yr BP.

Anumber ofmummified animals have been discovered in caves in Namibia, including a porcupine (Hystrix africanus) in Arnhem Cave (Marais, unpublished), and hyrax (Procavia capensis) and klipspringer (Oreotragus oreotragus) in Gauab Cave (Marais et al., 1996). In addition, mummified klipspringers were found in both Parakietgat Cave and Temple of Doom Cave near Sesfontein (Martini et al., 1991; Martini \& Marais, 1996). None of the Namibian mummified animals has ever been dated.

In 1982 an intact mummified adult female chacma baboon, subspecies Papio cynocephalus ursinus, was discovered on a ledge in Ludwig Cave in Namibia (Figs. 1 and 2A) by Mr. J. Loots, the owner of the cattle ranch on which the cave is situated (pers. comm. 2002). We (Marais) first saw the mummy, and three decomposing baboon corpses on the floor of a nearby passage, in July 1995. The rotting corpses were in an area of the cave receiving a small flow of water during the wet season, explaining their advanced state of decomposition. The microclimate of the ledge, which is dry and dusty, explains the mummification rather than decomposition of the female baboon. As the mummy had three upper and three lower molars, 
and as the $\mathrm{M}_{3}$ upper molars do not appear in female baboons until around 7 years of age (Smith et al., 1994), the animal had reached adulthood before death. In April 2002 another mummified baboon, a male juvenile, was discovered on a ledge near the adult female; it was not there in 1998. As none of the mummified animals found in Namibian caves has ever been dated, we did not know if the adult female baboon mummy was ancient or recent. This paper outlines our attempt to learn more about this mummified animal.

\section{LUDWIG CAVE}

Ludwig Cave is close to the border of the Etosha National Park, $40 \mathrm{~km}$ from Otavi, and $120 \mathrm{~km}$ from Grootfontein (Fig. 1). Average rainfall at Grootfontein is $550 \mathrm{~mm} / \mathrm{yr}$ (1898-1994) with $525 \mathrm{~mm} \mathrm{(95 \% )}$ coming in the six austral summer months November to April. The mean annual temperature is $20.2^{\circ} \mathrm{C}$ (1968-1989), with mean monthly values ranging from $24.4^{\circ} \mathrm{C}$ in December to $13.6^{\circ} \mathrm{C}$ in July (Table 1). The cave was reportedly discovered in the 1950s while local residents were searching for a burglar named Ludwig who according to local legend lived in the entrance pit. It is $335 \mathrm{~m}$ long and $43 \mathrm{~m}$ deep and has developed in slightly metamorphosed blue, Maieberg Formation limestone of the Tsumeb Subgroup. The entrance to the cave is a vertical solution pit $9 \times 4$ $\mathrm{m}$ and $9 \mathrm{~m}$ deep located near the top of a limestone ridge. Mamba Crawl, a low, wide passage, leads into the cave from the bottom of the entrance shaft but rapidly decreases in height to become impassable before connecting to the rest of the cave (Fig. 1). Access to the main system is through a larger passage $2.5 \mathrm{~m}$ above the floor at the northern end of the entrance pit. The floor of this opening is polished smooth by generations of baboons roosting in a small chamber behind it. A tunnel-like passage from this chamber continues for about $30 \mathrm{~m}$ and then slopes steeply downwards, ending in a $6 \mathrm{~m}$ drop (Rope Drop) into a passage running east to west. To the east this passage leads to a $5 \mathrm{~m}$ deep pit, the Dust Trough, which contained three decomposing baboon corpses in July 1995. To the west it leads upwards before curving north to join a larger northeast to southwest oriented passage. At the western end of the eastwest passage a small opening at floor level, $50 \mathrm{~cm}$ wide and $20 \mathrm{~cm}$ high, leads to Mamba Crawl. The female baboon mummy was found in the northeastto-southwest passage. In July 1995 temperature and humidity were recorded at various sites throughout the cave. Temperature averaged $24.2^{\circ} \mathrm{C}(\mathrm{n}=10, \sigma=$ $0.27)$ and relative humidity $74.9 \%(\mathrm{n}=10, \sigma=7.3)$ at floor level and $24^{\circ} \mathrm{C}$ with $66 \%$ humidity at the female mummy.

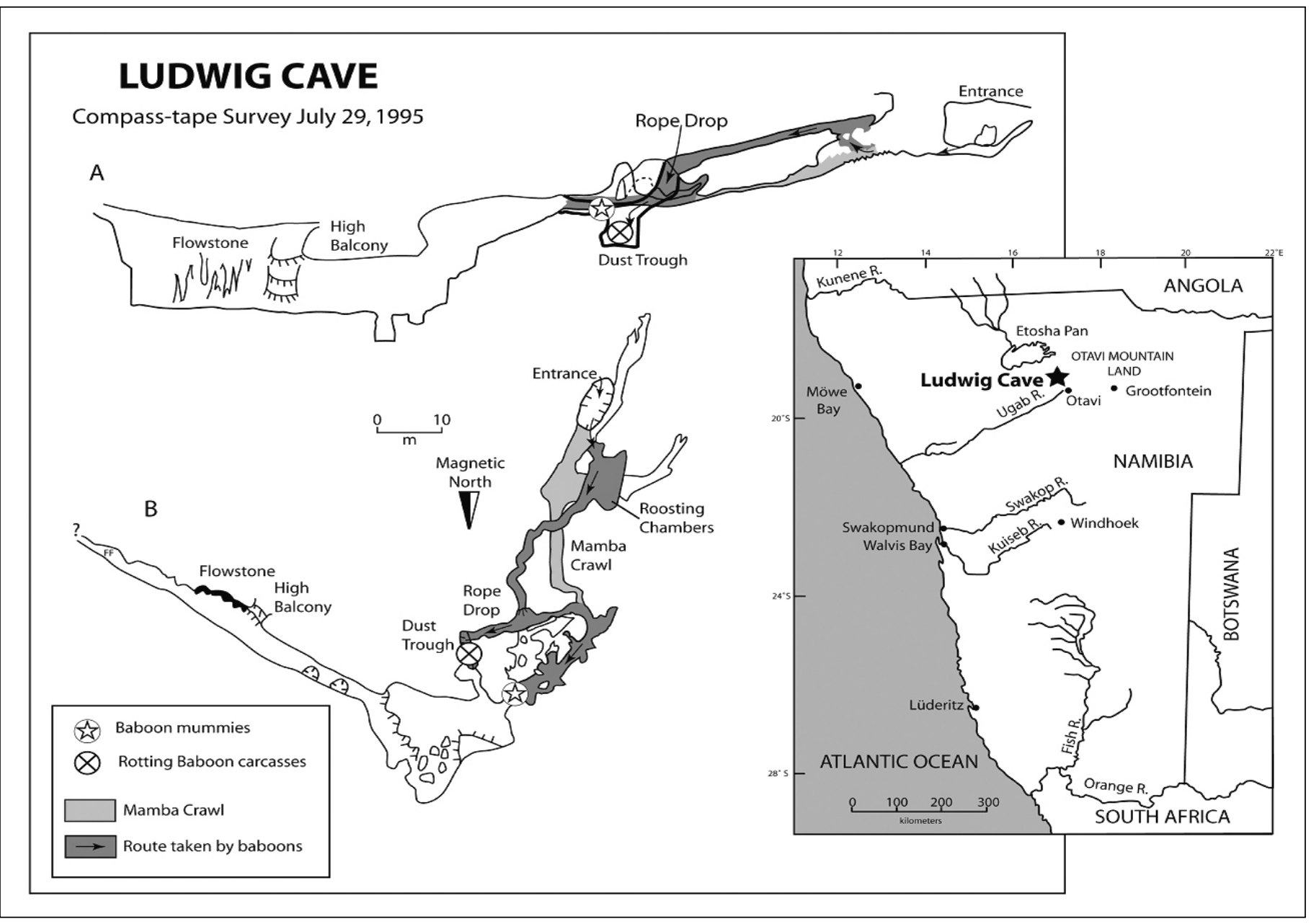

Fig. 1. Location of Ludwig Cave, Namibia (inset), and a simplified map and section showing where baboon remains were found, and how they probably entered the cave. 

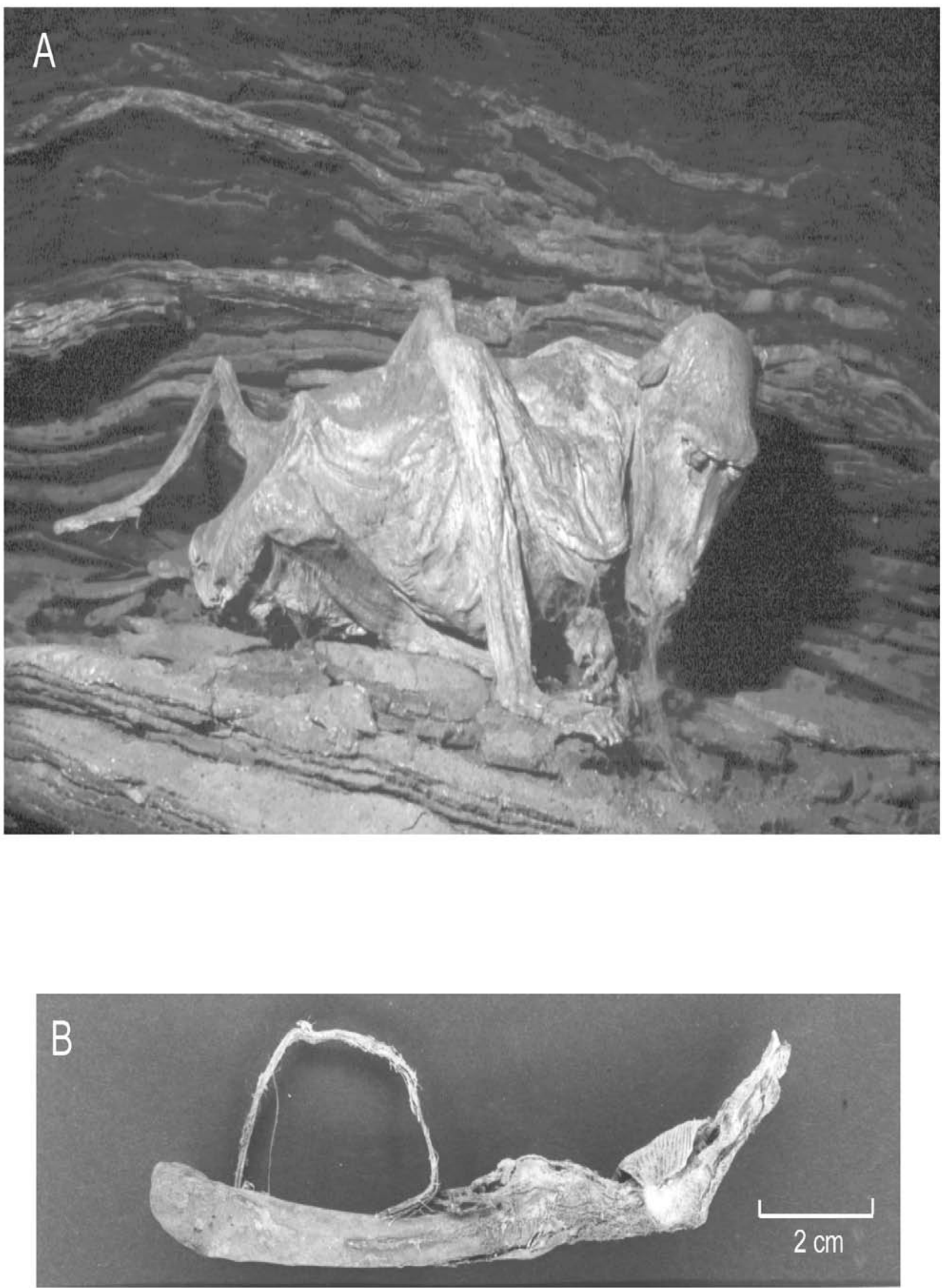

Fig. 2. Adult female mummified baboon discovered in 1982 (A) and the toe removed for scientific analysis (B). The baboon is $50 \mathrm{~cm}$ from crown to tail root. 


\begin{tabular}{|c|c|c|c|c|c|c|c|c|c|c|c|c|c|}
\hline & Jan & Feb & Mar & Apr & May & Jun & Jul & Aug & Sep & Oct & Nov & Dec & Year \\
\hline Rain $(m m)^{*}$ & 134 & 122 & 98 & 39 & 4 & 1 & 0 & 1 & 3 & 16 & 51 & 81 & 550 \\
\hline Temp $\left({ }^{\circ} \mathrm{C}\right)$ & 23.6 & 22.6 & 21.7 & 19.9 & 16.6 & 13.7 & 13.6 & 16.8 & 21.2 & 23.8 & 24.2 & 24.4 & 20.2 \\
\hline
\end{tabular}

* 1898-1994, **1968-1989

Table 1. Average Precipitation and temperature at Grootfontein, Namibia (after Peterson \& Vose, 1997).

\begin{tabular}{|c|c|c|c|}
\hline Material & Laboratory ID & Fractionation-corrected pMC & $\boldsymbol{\delta}^{13} \mathbf{C}(\%$ PDB) \\
\hline Bone collagen & UGAMS-0022 & $130.9 \pm 0.4$ & $-19.5 \pm 0.1$ \\
\hline Bone collagen & UGAMS-0022B & $132.1 \pm 0.7$ & $-19.5 \pm 0.1$ \\
\hline Tendon & UGAMS-0112 & $136.4 \pm 0.7$ & $-19.4 \pm 0.1$ \\
\hline Skin & UGAMS-132 & $135.1 \pm 0.7$ & $-19.6 \pm 0.1$ \\
\hline
\end{tabular}

Table 2. Percentage of modern carbon in bone, tendon, and skin from a mummified adult female baboon in Ludwig Cave, Namibia

\section{RADIOCARBON DATING}

To determine the age of the baboon mummy, bone collagen was first selected as the carbon source. The surface of the metatarsal was cleaned by abrasion and bone powder milled from the dense cortical tissue (Fig. 2B). Collagen was extracted from the bone powder using methods described by Bronk Ramsey et al. (2000). The collagen yield, $13 \%$ of the starting bone mass, indicated that the bone was reasonably well preserved. The purified collagen was combusted in a sealed, evacuated ampoule in the presence of $\mathrm{CuO}$. The resulting carbon dioxide was then cryogenically purified from the other combustion products. An aliquot was isolated and injected into a stable isotope ratio mass spectrometer. The $\delta^{13} \mathrm{C}$ was found to be $-19.5 \%$ o $\pm 0.1 \%$ o relative to the VPDB standard. This measurement was subsequently utilized for an isotope fractionation correction calculation.

The remaining carbon dioxide was catalytically converted to graphite using the method of Vogel et al. (1984). Graphite ${ }^{14} \mathrm{C} /{ }^{13} \mathrm{C}$ ratios were measured using the $0.5 \mathrm{MeV}$ accelerator mass spectrometer at the Center for Applied Isotope Studies, University of Georgia. The sample ratios were compared to the ratio measured from Oxalic Acid I (National Bureau of Standards, Standard Reference Material \#4990). The error is quoted as one standard deviation and reflects both statistical and experimental errors (Table 2).

By convention, the radiocarbon content of the atmosphere in AD 1950 has been given a value of $100 \%$. Since radioactive decay reduces the ${ }^{14} \mathrm{C}$ content of organic remains over time, the age of organic materials can be expressed in terms of \% modern carbon (pMC). The ${ }^{14} \mathrm{C}$ content of the baboon bone collagen was found to be $130.9 \% \pm 0.4 \%$ modern, considerably higher than the AD 1950 value. Because of this unusual finding the metatarsal was sampled a second time at a different location and the measurements repeated. The second result $(132.1 \% \pm 0.7 \%)$ confirmed the first measurement. These super modern values indicate the presence of ${ }^{14} \mathrm{C}$ from atomic bomb testing, and established that the animal lived after AD 1950.

Radiocarbon measurements were then carried out on tendon and skin samples in an attempt to more precisely identify when the animal lived. A sample of tendon was initially given the standard acid/base/acid chemical pretreatment used for the extraction of collagen from bone. The recovery was unacceptably low suggesting that the tendon collagen was in a fragmentary state. A second tendon sample was pretreated by suspension in $0.5 \mathrm{M} \mathrm{HCl}$ for one hour at room temperature. The swelled tendon was then washed in deionized water until the $\mathrm{pH}$ of the wash solution increased to 4.0. The tissue was then lyophilized, combusted, and graphitized for AMS measurement in the manner described for bone collagen. A sample of skin was also prepared using the same acid-only treatment. This minimal treatment would remove bulk contaminants, carbonate salts, and a fraction of the weakly bound contaminants. Omitting the high $\mathrm{pH}$ treatment seemed reasonable as mummification requires a dry environment and the baboon was never buried: contamination by basesoluble, soil-derived humic acids seemed unlikely. AMS of graphitized tendon and skin samples revealed that the tendon contained $136.4 \% \pm 0.7 \%$ modern carbon, and the skin $135.1 \% \pm 0.7 \%$ modern carbon (Table 2). Comparison of the skin value with Southern Hemisphere atmospheric ${ }^{14} \mathrm{C}$ values shown in Figure 3 indicates that atmospheric levels passed through these values in September 1963 and between April and December 1976. The actual date of death occurred after this, and a discussion of the lag time is presented below.

\section{DISCUSSION}

Above ground nuclear testing raised atmospheric ${ }^{14} \mathrm{C}$ levels in the late 1950s and early 1960 s well above natural levels. The incorporation of 'bomb carbon' 


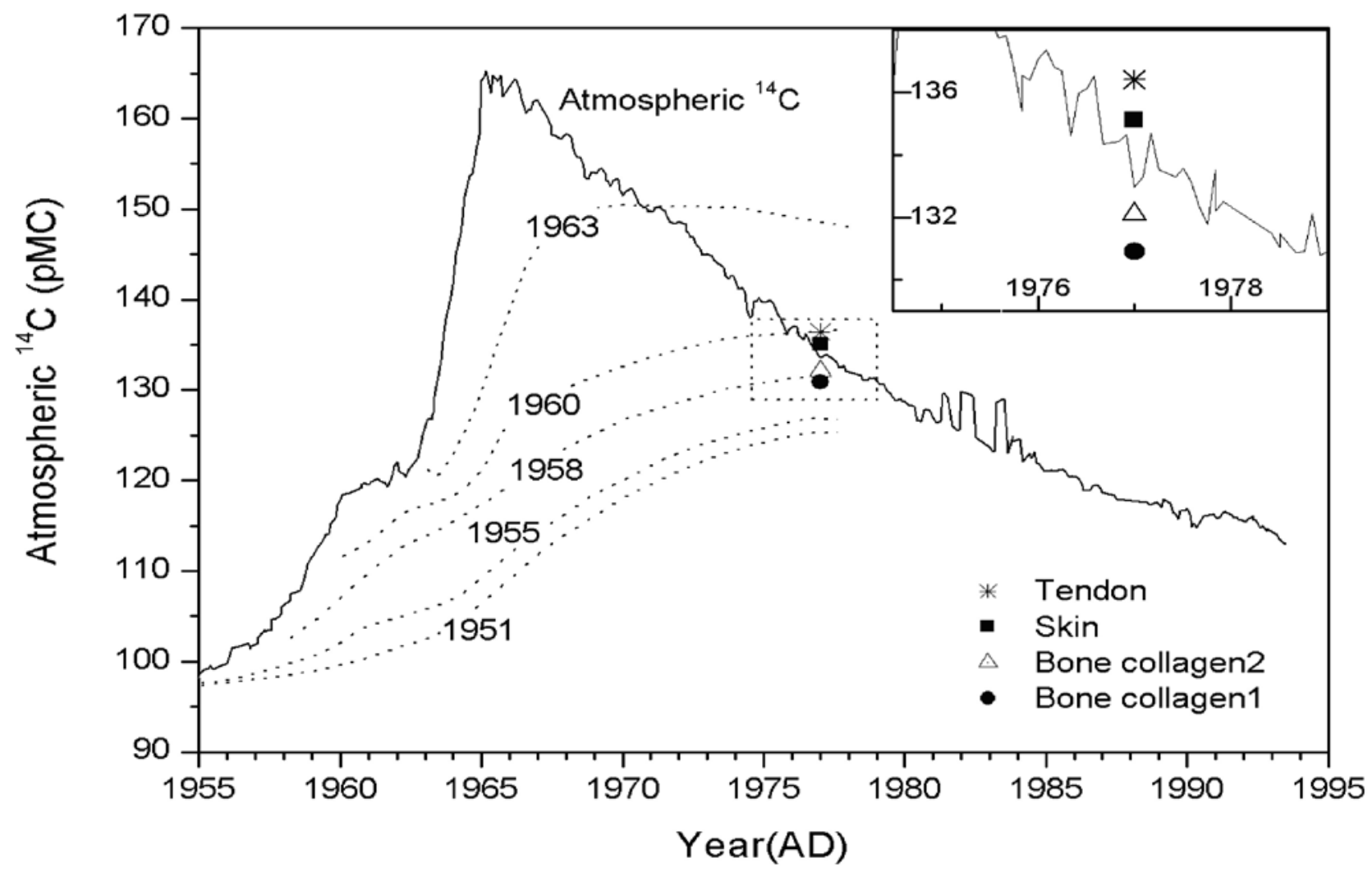

Fig. 3. Modeling changes in bone collagen radiocarbon content for different birth years based on atmospheric ${ }^{14} \mathrm{C}$ levels for the Southern Hemisphere 1955-1994. The ${ }^{14} \mathrm{C}$ data have been plotted as a 3 point running average of measurements made in Wellington, New Zealand and published in Manning et al. 1990, and Manning \& Melhuish 1994. The bone, tendon, and skin ${ }^{14} \mathrm{C}$ measurements are plotted on the curve. The $Y$ error bars are contained within the symbols used. Models assume that the adult female baboon died in 1977. The best model suggests that the baboon was born in 1958, indicating an age at death of 19 years.

indicates that the animal lived during this period (Fig. 3). This brief pulse of ${ }^{14} \mathrm{C}$ into the atmosphere has been referred to as the 'bomb-spike' and it has been used in ${ }^{14} \mathrm{C}$ dating for authentication studies and forensic science.

Forensic studies have been aimed at establishing either the date of death, or the age at time of death, both of which require an understanding of the transfer of ${ }^{14} \mathrm{C}$ from the atmosphere into tissues. The factors that affect this are the nature of the food chains incorporating ${ }^{14} \mathrm{C}$ into diet, the metabolic routing of dietary carbon between energy production and tissue synthesis, and the residence time/turnover rate of carbon within different tissues. Sex, genetics, behavior, disease and other factors are likely to modulate tissue ${ }^{14} \mathrm{C}$ content.

Broecker et al. (1959), Libby et al. (1964), and Stenhouse \& Baxter (1977) all studied the uptake of bomb ${ }^{14} \mathrm{C}$ in various human tissues. The estimates attempted to account for the omnivorous human diet, and included assessments of the lag time between food growth and consumption for various categories of foodstuffs. In their estimates, dietary inputs from fruits, vegetables, and dairy products were most tightly linked to atmospheric ${ }^{14} \mathrm{C}$ levels whereas cereals, meats, and fish contained ${ }^{14} \mathrm{C}$ levels lagging well behind the contemporary atmosphere. They all estimated about a one-year lag for ${ }^{14} \mathrm{C}$ levels in soft tissue to reflect atmospheric levels. Thus the ${ }^{14} \mathrm{C}$ content of soft tissues provides the most reliable data for establishing the date of death.

This approach is well illustrated by Wild et al. (2000). They measured the bomb- ${ }^{14} \mathrm{C}$ content of human hair, bone lipid, and bone collagen and from individuals of known age and date of death. They determined that the ${ }^{14} \mathrm{C}$ content of hair (a continuously synthesized, non-turning over tissue) lagged approximately one year behind the atmospheric levels, whereas lipid ${ }^{14} \mathrm{C}$ content lagged six years and bone collagen ${ }^{14} \mathrm{C}$ between twenty and thirty years behind atmospheric levels.

Clearly collagen is a less than ideal material for bomb-spike determinations of date of death. However its longer turnover time suggests it might be useful for establishing age at time of death, although a detailed understanding of collagen residence time is required. Studies have shown that collagen residence time in human bone is variable. Much of this variability has been attributed to life stage: brief during growth and development, stable at about 20 years in adult life (Stenhouse \& Baxter 1977) but possibly extending to greater than 30 years in elderly individuals (Stenhouse \& Baxter 1977, Wild et al. 2000). Jull et al. (1995) presented data showing residence time could vary within adults by a factor of two. Although the reason for this was unknown, differences in nutritional history were suspected. This variability confounded attempts to determine age at time of death based upon collagen ${ }^{14} \mathrm{C}$ content. 
In this study, we feel confident in our determination of the year of death for the baboon as 1977. In spite of the fact that our understanding of the rate of ${ }^{14} \mathrm{C}$ flow from the atmosphere through vegetation and into the baboon's tissue is limited, encompassing these uncertainties using the one-year lag identified by Wild et al. seems reasonable. Our measurements were on baboon skin rather than hair, and ${ }^{14} \mathrm{C}$ in skin may have a longer residence time. However, we feel this potential increase in residence time is offset by the fact that the baboon is frugivorous (fruit-eating). Thus, its dietary ${ }^{14} \mathrm{C}$ intake is more tightly linked to atmospheric ${ }^{14} \mathrm{C}$ levels than the average human diet.

We also carried the study further and attempted to estimate the year of birth, and hence age at time of death. Observation indicated that the baboon was of adult size. Female baboons reach full size at about 5-6 years and life expectancy is 27 years, while male baboons reach full size at 7-8 years and life expectancy is 22 years (Susan Alberts, pers. comm. 2001). If the mummified baboon was born after 1960, then uptake of bomb ${ }^{14} \mathrm{C}$ during early development would result in bone collagen ${ }^{14} \mathrm{C}$ levels being higher than tendon and skin. The fact that the bone ${ }^{14} \mathrm{C}$ levels are lower than soft tissue points toward the baboon developing to adulthood before or during the early part of the bomb spike, and slowly incorporating bomb ${ }^{14} \mathrm{C}$ through steady-state turnover. This reasoning places the birth of the baboon around 1957 on the rising limb of the bomb spike curve, some 6 years prior to 1963 (6 years to adulthood) when atmospheric ${ }^{14} \mathrm{C}$ was the same as that of the baboon's bone collagen at the time of death in 1977. A rough age for the baboon at death is therefore 20 years, which suggests that the residence time of baboon bone collagen is similar to that of humans.

Modeling collagen radiocarbon uptake using estimates of collagen turnover rates generated a more sophisticated estimate. Although collagen turnover in baboons has not been studied, our first hypothesis was that allometric scaling from human to baboon might be used to approximate a residence time for baboon bone collagen. If steady-state collagen turnover is linked to basal metabolic rate then a scaling factor, such as Kleiber's Law, which correlates body mass with basal metabolic rate, or Hofman's correlation between longevity, brain mass and basal metabolic rate, might be used to estimate collagen turnover time (see discussions in Austad \& Fischer 1992). Most formulae imply that turnover rates in baboons should be equal to or slightly less than in humans.

Jull et al. (1985) modeled bomb ${ }^{14} \mathrm{C}$ uptake into human bones using box modeling. We took a similar approach. Our model is based on three important assumptions. First, bone collagen ${ }^{14} \mathrm{C}$ levels are determined directly from food, and that herbivore food ${ }^{14} \mathrm{C}$ levels lag one year behind atmospheric levels (see Broecker et al., 1959; Libby et al., 1964; and Stenhouse $\&$ Baxter, 1977). Second, during skeletal growth (the first 6 years in our model) bone mass accumulates linearly to $3 \mathrm{~kg}$ (Altmann \& Alberts (2005) show a linear increase in body mass to adulthood) and newly formed bone ${ }^{14} \mathrm{C}$ levels track food ${ }^{14} \mathrm{C}$ levels. Third, after adult size is attained, bone collagen turns over at a rate of $5 \%$ of the bone mass every year. This collagen turnover rate is based upon turnover rates in human collagen determined by Libby et al. (1964), Stenhouse $\&$ Baxter (1977), and Wild et al. (2000). The ${ }^{14} \mathrm{C}$ content of the replacement bone is assumed to follow atmospheric ${ }^{14} \mathrm{C}$ levels with a one-year lag as explained above. Jull et al's model also incorporates a slowdown in human bone collagen turnover rate to $3 \%$ per year after the age of 65 , but this aspect was omitted from our model. In modeling, the accumulation of ${ }^{14} \mathrm{C}$ in baboon skeletal collagen was calculated from the atmospheric ${ }^{14} \mathrm{C}$ values plotted in Figure 3 using the three-component algorithm discussed above. Different scenarios were examined by assuming different birth years, modeling the accumulation of ${ }^{14} \mathrm{C}$ in bone over time, and selecting the birth year that most closely predicted bone collagen ${ }^{14} \mathrm{C}$ levels fixed in 1977. Plots using the model based on birth years of 1951, 1955, 1958, 1960 and 1963 are shown in Figure 3. The model suggests that a birth year of 1958 most closely predicts the observed bone ${ }^{14} \mathrm{C}$ level at the time of death (1977). From this an age at time of death was calculated to be 19 years.

When we visited the cave in 2002 there was a second mummified baboon, a juvenile male, on a ledge below the mummy of the adult female. There were pupal cases of Calliphoridae (Diptera) on the stomach area of the new mummy, which was not there when we visited the cave in 1998. As the animal had been in the cave less than 5 years, mummification is clearly rapid in this semiarid cave despite relatively high cave humidity.

An obvious question is why baboons might venture into Ludwig Cave. One possibility is that unresponsive females, immature males, or low status males, may have tried to escape the hassling of higher status males or females by running deeper into the cave (there is a lot of noise and general mayhem before baboons settle down at night). Another possibility is that leopards, their main predator, attempted to prey on the troop at night. If attacked by leopards during the day baboons will usually defend themselves and have been known to kill their attackers. However, at night they do not defend themselves but rather run off in all directions-some possibly deeper into the cave. Leopards are mainly nocturnal hunters and relatively common in the area around Ludwig Cave so this explanation is extremely plausible.

During our 2002 visit to the cave, the 'Rope Drop' was extremely slippery due to recent rains. Despite having a rope and ascenders it was difficult to get up the ca. $6 \mathrm{~m}$ slope. We believe that under wet conditions baboons descending the 'Rope Drop' would be unable to climb out. They may have been attracted to the 'Mamba Crawl' because of a strong airflow along this passage and a small amount of light during the day, but found the opening too small $(20 \mathrm{~cm}$ high by 50 $\mathrm{cm}$ wide) to pass. Being lost in the dark, the animals probably ended up sitting on ledges eventually dying of dehydration or famine. 
On Mount Suswa, Kenya, baboons frequently occupy collapse entrances to lava tube caves and their bones are numerous in some caves, possibly carried there by leopards (Glover et al., 1964). Bones of baboons, many of them extinct, are common in breccias of caves such as Sterkfontein, Swartkrans, and Kromdraai in South Africa (e.g. Brain, 1958, 1981) and in Bone Cave in Botswana (Callum Ross, pers. comm. 2000). For example, Brain (1981) reports 181 baboons among 331 animals represented in Sterkfontein Member 4, along with 45 specimens of Australopithecus africanus. In Swartkrans Member 1, 89 of 312 animals are baboons, 3 Homo sp. and 85 are Australopithecus robustus, while in Kromdraai B, 32 of 86 animals are baboons and six are Australopithecus robustus. One possibility for the preponderance of baboons in these cave breccias is that these South African caves, like Ludwig Cave in Namibia, could be entered easily but were sometimes difficult to escape from. In fact, many caves in the dolomites of Southern Africa, including several with Australopithecus and baboon remains, have or used to have vertical entrances with steep to overhanging walls. This very common cave morphology results from solutional development at or near the groundwater table, followed by roof collapse and opening of the cave to the surface (e.g. Brink and Partridge, 1965). Over a long period of time it is possible that a large number of baboons were chased into these caves where they became trapped and died from dehydration and starvation. Some of these animals were probably injured by the fall into the vertical cave entrance; perhaps others could not climb out because of the steepness or overhanging nature of the entrance walls.

\section{CONCLUSIONS}

The two mummified baboons and three decaying corpses in Ludwig Cave, Namibia suggest that baboons ran into the cave and became trapped because of harassment by other baboons or because a leopard attempted to prey on the troop at night. We believe that this may have occurred during the wet season and that once the animals slid down the 'Rope Drop' they found the slope too slippery to climb out. The mummified animals died on ledges as a result of dehydration or famine. As the male juvenile baboon had been in the cave less than 5 years when discovered, mummification is clearly rapid in this semiarid climate despite relatively high humidity in the cave. pMC values of greater than 100 for bone, tendon and skin from the adult female mummy suggest death in late 1977 according to the atomic bomb spike calibration curve of Manning et al. (1990) and Manning \& Melhuish (1994). The animal was likely around 19 years old at the time of death, based upon the relative ${ }^{14} \mathrm{C}$ content of bone collagen and soft tissue collagen. The young age of the baboon mummy suggests that other mummified animals in Namibian caves may also be of relatively recent age. Our studies indicate that where there are no other indications of an animal's age, pMC measurements of skin plus that of bone collagen, together with knowledge of the animal's growth characteristics, can provide an estimate of age at the time of death. The bomb-spike age calibration approach used here to date the mummified baboon in Ludwig Cave can be used to date the remains of any animal or human that died within about the last 45 years.

\section{ACKNOWLEDGEMENTS}

This research was supported by NSF grant BCS0002193 to Brook. The authors thank Mr. Dieter Muhle and Mr Jan Loots for permission to visit the cave and John Irish for assistance in the field.

\section{REFERENCES}

Altmann, J. \& Alberts, S.C., 2005 - Growth rates in a wild primate population: ecological influences and maternal effects. Behavioral Ecology and Sociobiology, 57: 490-501.

Austad, S.N. \& Fischer K.E., 1992 - Primate longevity: its place in the mammalian scheme. American Journal of Primatology, 28:251-261.

Brain C.K., 1958 - The Transvaal Ape-Man Bearing Cave Deposits. Transvaal Museum Memoirs No. 11.

Brain C.K., 1981 - The Hunters or the Hunted? An Introduction to African Cave Taphonomy. University of Chicago Press, Chicago.

Brink A.B.A. \& Partridge T.C., 1965 - Transvaal karst: some considerations of development and morphology. The South African Geographical Journal, 47: 11-34.

Broecker W.S., Schulert A. \& Olson E.A., 1959 - Bomb carbon-14 in human beings. Science, 130: 331-332.

Bronk Ramsey, C., Pettitt P.B., Hedges R.E.M., Hodgins G.W.L. \& Owen D.C., 2000 - Radiocarbon dates from the Oxford AMS system: Archaeometry Datelist 30. Archaeometry, 42(2): 459-479.

Glover P.E., Glover E.C., Trump E.C. \& Wateridge L.E.D., 1964 - The lava caves of Mount Suswa, Kenya. Studies in Speleology, 1: 51-66.

Jull A.J.T., Kalin R.M. \& Burns K., 1985 - Bomb-derived ${ }^{14} \mathrm{C}$ in human bones: AMS application to forensic science. American Chemical Society, 205 $5^{\text {th }}$ Annual Meeting, Anaheim, CA, April 1985.

Libby W.F., Berger R., Mead J.F., Alexander G.V. \& Ross J.F., 1964 - Replacement rates for human tissue from atmospheric radiocarbon. Science, 146: 1170-1172.

Lowry D.C. \& Lowry J.W.J., 1967 - Discovery of a Thylacine (Tasmanian tiger) carcass in a cave near Eucia, Western Australia. Helictite, 5: 25.

Lowry J.W.J. \& Merrliees D., 1969 - Age of the desiccated carcass of a Thylacine (Marsupiala Dasyuriodea) from Thylacine Hole, Nullarbor region, Western Australia. Helictite, 7: 15-16.

Manning M.R., Lowe D.C., Melhuish W.H., Sparks R.J., Wallace G., Brenninkmeijer C.A.M. \& McGill R.C., 1990 - The use of radiocarbon measurements in atmospheric studies. Radiocarbon, 32: 37-58.

Manning M.R. \& Melhuish W.H., 1994 - Atmospheric ${ }^{14} \mathrm{C}$ record from Wellington. In: Trends: A Compendium of Data on Global Change. Carbon Dioxide Information 
Analysis Center, Oak Ridge National Laboratory, U.S. Department of Energy, Oak Ridge, Tenn., U.S.A.

Marais J.C.E., Irish J. \& Martini J.E.J., 1996 - Cave investigations in Namibia V: 1993 SWAKNO results. Bulletin of the South African Spelaeological Association, 36: $58-78$.

Martini J.E.J. \& Marais J.C.E., 1996 - Grottes hydrothermales dans le nord-ouest de la Namibie. Spéléogénèse et implication dans le développement des karsts en climat arid. Karstologia, 28 (2): 13-18.

Martini J.E.J., Marais J.C.E. \& Irish J., 1991 - Kaokoveld karst, Namibia. Bulletin of the South African Spelaeological Association, 31: 25-41.

Peterson T.C. \& Vose R.S., 1997 - An overview of the global historical climatology network temperature data base. Bulletin of the American Meteorological Society, 78: $2837-2849$.
Smith H.B., Crummett T.L. \& Brandt K.L., 1994 Ages of eruption of primate teeth: A compendium for aging individuals and comparing life histories. Yearbook of Physical Anthropology, 37: 177-231.

Stenhouse M.J. \& Baxter M.S., 1977 - Bomb ${ }^{14} \mathrm{C}$ as a biological tracer. Nature, 267: 828-832.

Vogel J.S., Southon, J.R., Nelson, D.E. \& Brown, T.A., 1984 - Performance of catalytically condensed carbon for use in accelerator mass spectrometry. Nuclear Instruments and Methods in Physics Research, B5: 289-293.

Wild E.M., Arlamovsky K.A., Golser R., Kutschera W., Priller A., Puchegger S., Rom W., Steier P. \& Vycudilik W., $2000-{ }^{14} \mathrm{C}$ dating with the bomb peak: An application to forensic medicine. Nuclear Instruments and Methods in Physics Research B172: 944-950. 